\title{
AKULTURASI BUDAYA MELAYU DALAM TERJEMAH AL QURAN (Studi Signifikansi Bahasa al-Quran Terjemahan terhadap Pemahaman Islam di Sumatera Selatan) Oleh: Anisatul Mardiah anisatul178@gmail.com
}

\begin{abstract}
Acculturation can also be called the process of spreading culture or cultural transmission in process. In disseminating the contents of the al-Quran among Muslims who are not Arabic, translation is certainly a necessity that must be fulfilled. Al-Quran translation in nusantara Indonesia has been going on since the 17th century. Beginning with Hamzah Fansuri, an ulama of Aceh, in the following period, the al-Quran was translated into various regional languages as well as Malay. Translation also became the main transmission line of the al-Quran to have direct dialogue with non-Arab Muslims, which turned out to be able to bring people towards advanced and more valuable civilizations. Especially in the South Sumatra region, the spread of the al-Quran and its translation in local languages made the ummah closer to the teachings of Islam. In the end, it was difficult to distinguish between acculturation and assimilation of Islam in various Malay customs and cultures in all areas of human life, because at the peak of the Malay slogan based on Shari'ah, Shari'ah based on the Koran and Hadith, is a real picture of the Malay of South Sumatr's life pattern based on Islam.
\end{abstract}

Keywords : Acculturation, Malay, Al-Quran, Translation

\begin{abstract}
Abstrak
Akulturasi juga bisa disebut proses penyebaran budaya atau transmisi budaya dalam proses. Dalam menyebarluaskan isi al-Quran di kalangan umat Islam yang bukan Arab, penerjemahan tentu saja merupakan keharusan yang harus dipenuhi. Terjemahan Al-Quran di nusantara Indonesia telah berlangsung sejak abad ke-17. Dimulai dengan Hamzah Fansuri, ulama Aceh, pada periode berikutnya, al-Quran diterjemahkan ke berbagai bahasa daerah dan juga bahasa Melayu. Terjemahan juga menjadi saluran transmisi utama al-Quran untuk melakukan dialog langsung dengan Muslim non-Arab, yang ternyata mampu membawa orang ke arah peradaban maju dan lebih bernilai. Khususnya di wilayah Sumatera Selatan, penyebaran alQuran dan terjemahannya dalam bahasa lokal membuat umat lebih dekat dengan ajaran Islam. Pada akhirnya, sulit untuk membedakan antara akulturasi dan asimilasi Islam dalam berbagai adat istiadat dan budaya Melayu di semua bidang kehidupan manusia, karena pada puncak slogan Melayu berdasarkan Syariah, Syariah berdasarkan Quran dan Hadits, adalah gambaran nyata dari pola hidup Melayu Sumatera Selatan berdasarkan Islam.
\end{abstract}

Kata kunci: Akulturasi, Melayu, Al-Quran, Terjemahan 


\section{A. Pendahuluan}

Mendeskripsikan Melayu dalam peta teritorial hingga kini masih mengundang diskusi yang serius dan panjang. Kebesaran nama Melayu bukan hanya berasal dari kekayaan negeri yang menaunginya saja,namun juga karena memang tersimpan banyak potensi nyata dari para petualang unggul ini. Pergerakan orang Melayu yang tidak pernah dibatasi oleh ruang dan waktu dapat dibuktikan dengan jejak sejarah yang mereka tinggalkan. Salah satu hal yang dapat dilihat hingga kini adalah jejak bahasa yang termaktub dalam penerjemahan al-Quran. Dalam catatan para ahli sejerah Melayu diperoleh keterangan bahwa perkembangan Islam di wilayah Nusantara telah melewati kurun waktu yang panjang. Proses perkembangan ajaran Islam ini dapat dilihat dari prilaku Islam yang terus berkembang dalam kepribadian orang Melayu yang tidak hanya tersebar di wilayah Kepulauan Sumatera saja.

Azas Syari'ah yang bersumber dari al-Quran dan al-Hadits, menjadi basis pemahaman budaya Melayu dan menjadi pondasi munculnya berbagai pemahaman keagamaan mereka. Ekspresi keilsaman ini dapat ditemukan dalam semua lini kehidupan masyarakat Melayu sampai sekarang. Hingga identitas Islam begitu melekat dalam kepribadian masyarakat Melayu. Bahkan ajaran Islam, oleh sebagian ahli sejarah Melayu, dianggap sebagai sumber peradaban masyarakat Melayu kuno hingga menjadi lebih modern. Namun sebagian lainnya berpendapat bahwa pergeseran prilaku orang Melayu lebih disebabkan oleh pengaruh prilaku kaum Arab yang menjadi aktor utama tersebarnya ajaran Islam di tanah Melayu. Fenomena utama dari asumsi tadi adalah akibat dari munculnya al-Quran yang menjadi basis ajaran Islam, yang secara terbuka dipelajari oleh umat Islam. AI-Quran yang muncul dalam bahasa Arab justru menjadi ajang berkembangnya ilmu pengetahuan mengenai kebahasaan di bumi manapun ia berada. Tak luput pula budaya kebahasaan yang muncul kemudian sebagai akibat dari perpaduan budaya bahasa Melayu dan Arab yang sangat intens bersinggungan dalam bentuk terjemahan alQuran.

Diberbagai wilayah di Indonesia bahkan diseluruh dunia, temuan mengenai terjemahan al-Quran dalam berbagai bahasa bukanlah menjadi hal baru. Berangkat dari membaca terjemahan tersebut, mayoritas umat Islam non Arab dapat mendekati ajaran Islam bahkan menyebarkannya menjadi lebih terstruktur dan intens. Penerjemahan al-Quran adalah jalan lain bagi Islam untuk berdialog dengan seluruh manusia non Arab dalam bahasa dan budaya mereka. Dalam tradisi pengajaran alQuran, membaca dan mempelajari tafsir ayat-ayat al-Quran juga menjadi bagian yang tak kalah pentingnya untuk dipelajari, namun membaca makna secara tekstual adalah langkah dasar untuk memahami kalam Allah tersebut. Oleh karena itu, dalam tradisi keilmuan al-Quran membaca terjemahan (bagi umat non Arab) adalah langkah dasar untuk mempelajari rahasia Islam dalam al-Quran.

\section{B. Pembahasan}

Di pusat wilayah Asia Tenggara, khususnya Semenanjung Melayu,dan Sumatera, terdapat banyak bukti tentang Islamisasi di kawasan ini yang berlangsung dalam kurun enam abad. Banyak aspek tentang kehidupan keluarga, struktur sosial, hukum, dan sistem pemerintahan terbentuk oleh pengaruh Islam, serta sejumlah kosa kata Arab terintrodusir ke dalam beberapa bahasa lokal seperti Melayu dan Sumatera. Hingga era modern ini, bentuk adaptasi huruf atau tulisan Arab masih banyak digunakan, baik dalam karya-karya bertema Islam maupun yang bertema sekuler. Selain itu, banyak karya sastra dan keagamaan yang berasal dari bahasa 
Arab atau terinspirasi oleh sumber-sumber berbahasa Arab, dan sedikit pengaruh Persia.

Selama satu milenium, bahasa Melayu menjadi bahasa yang paling banyak digunakan di kawasan ini, dan sejak awal Abad XV, bahasa ini memiliki peran khusus dalam dakwah Islam. Peran ini terdokumentasi dalam beberapa manuskrip Melayu yang terpelihara dalam perpustakaan lokal, museum, koleksi keluarga, serta beberapa lembaga di Eropa. Banyak di antaranya yang muncul sebelum akhir Abad $\mathrm{XVI}$ dan tidak memberi gambaran yang lengkap tentang transmisi dan perkembangan disiplin keilmuan tradisional yang menjadi dasar kehidupan umat Islam, seperti tafsir, hadis, dan fikih. Banyak karya yang terkait dengan disiplin tersebut ditemukan di pusat-pusat kota yang biasanya merupakan kota pelabuhan di sepanjang Nusantara. Karya-karya ini tidak mencapai jumlah yang signifikan, yang diharapkan dapat menarik perhatian para peneliti, atau menjadi standar riset tentang Islam di kawasan tersebut.

Jalur penyebaran Islam di Indonesia lebih didominasi oleh jalur yang melalui perangkat budaya. Ajaran Islam yang ditanamkan melalui perangkat budaya ini, mau-tidak mau, menyisakan warisan agama lama dan kepercayaan yang ada, yang tumbuh subur di masyarakat pada waktu itu, untuk dilestarikan kemudian dibersihkan dari anasir syirik. Pembersihan anasir syirik ini merupakan satu upaya untuk meneguhkan konsep monoteisme (tauhid) dalam ajaran Islam. Fakta bahwa orang Melayu adalah kaum penjelajah, merupakan gambaran nyata bahwa orang Melayu memiliki kepribadian terbuka yang merupakan jalan bagi sikap penerimaan kaum Melayu terhadap hal-hal baru.

Ciri utama orang Melayu adalah orang-orang yang beragama Islam dan menjadi muslim yang taat, sehingga ketaatan terhadap aqidahnya tersebut tercermin dalam adat budaya yang tercipta, pasca tersebarnya Islam di wilayah mereka. Berdasarkan catatan sejarah bahwa ajaran Islam pertama kali masuk ke Nusantara, khususnya pantai Timur Sumatera, dan sepanjang Selat Malaka, sejak abad ke-7 Masehi para pedagang Arab membawa ajaran ini. Pada perjalanan menuju Selat Malaka, para pedagang tersebut mampir di Malabar, Cambay, dan Gujarat (India). Sejak itu, Islam berpengaruh terhadap budaya dan menentukan pertumbuhan juga perkembangannya. Kawasan Nusantara sendiri didiami oleh penduduk yang berbudaya Melayu, maka dengan sendirinya telah terjadi persebaran pengaruh agama Islam terhadap masyarakat Pantai Timur dan Selat Malaka.

Al-Quran yang kandungannya menjadi pusat ajaran Islam, adalah kitab yang wajib dipahami oleh pemeluknya. Oleh karenanya, pembelajaran mengenai bacaan dan segala sesuatu mengenai al-Quran menjadi konsentrasi utama umat muslim dari masa ke masa. Al-Quran yang berbahasa Arab memerlukan penterjemahan ke dalam bahasa lokal untuk mencapai target pemahaman terhadap umat yang tersebar di berbagai pelosok daerah. Dalam hal ini, penterjemahan al-Quran yang aslinya berbahasa Arab, tentunya menjadi sangat mendesak untuk dilakukan. PenerjemahanAI-Quran ke dalam bahasa Melayu telah dilakukan sejak pertengahan abad ke-17 M. Adalah Abdul Ra'uf Fansuri, seorang ulama dari Singkel (sekarang masuk wilayah Aceh) yang pertama kali menerjemahkan Al-Quran secara lengkap di bumi Nusantara. Meski terjemahannya boleh disebut kurang sempurna dari ditinjauan ilmu bahasa Indonesia modern, Abdul Ra'uf Fansuri bisa dikatakan sebagai tokoh perintis penerjemahan AI-Quran berbahasa Indonesia.

Sejak akhir tahun 1920-an dan seterusnya, sejumlah terjemahan al-Qur'an dalam bentuk juz per juz, bahkan seluruh isi al-Qur'an mulai bermunculan. Kondisi penerjemahan al-Qur'an semakin kondusif setelah terjadinya sumpah pemuda pada 
tahun 1928 yang menyatakan bahwa bahasa persatuan adalah bahasa Indonesia. Tafsir Al-Furqân misalnya adalah tafsir pertama yang diterbitkan pada tahun 1928 . Selanjutnya, atas bantuan seorang pengusaha, yaitu Sa'ad Nabhan, pada tahun 1953 barulah proses penulisannya dilanjutkan kembali hingga akhirnya tulisan Tafsir Al-Furqân secara keseluruhan (30 juz) dapat diterbitkan pada tahun 1956. Pada tahun 1932, Syarikat Kweek School Muhammadiyah bagian Karang Mengarang dengan judul "al-Qur'an Indonesia", Tafsir Hibarna oleh Iskandar Idris pada tahun 1934, Tafsir asy-Syamsiyah oleh KH. Sanusi. Pada tahun 1938, Mahmud Yunus menerbitkan Tarjamat al-Qur'an al-Karim. Kemudian pada tahun 1942, Mahmud Aziz menyusun sebuah tafsir dengan judul Tafsir Qur'an Bahasa Indonesia. Proses terjemahan semakin maju pascakemerdekaan RI pada tahun 1945 yaitu munculnya beberapa terjemahan seperti al-Qur'an dan Terjemahnya yang didukung oleh Menteri Agama pada saat itu. Pada tahun 1955 di Medan dan dicetak ulang di Kuala Lumpur pada tahun 1969, diterbitkan sebuah tafsir dengan judul Tafsir al-Qur'an alKarim yang disusun oleh tiga orang yaitu A. Halim Hasan, Zainal Arifin Abbas dan Abd Rahim Haitami .

Pada tahun 1963, perkembangan terjemahan mulai tampak dengan munculnya Tafsir Qur'an karya Zainuddin Hamidi dan Fachruddin HS. Tafsir al-Azhar yang ditulis oleh Hamka pada saat dalam tahanan di era pemerintahan Soekarno dan diterbitkan untuk pertama kalinya pada tahun 1966. Kemudian pada tahun 1971, "Tafsir al-Bayan" dan pada tahun 1973 "Tafsir al-Qur'an al-Madjied an-Nur, dicetak juz per juz yang keduanya disusun oleh Hasbi al-Shiddiqy disamping menterjemahkan secara harfiah dengan mengelompokkan ayat-ayatnya juga menjelaskan fungsi surah atau ayat tersebut, menulis munasabah dan diakhiri dengan kesimpulan. Bentuk karya Hamka lebih kepada ensiklopedis karena dia seorang novelis dan orator sedangkan al-Shiddiqy menggunakan bahasa prosa.

Setelah itu, satu persatu karya-karya tafsir mulai bermunculan seperti “Keajaiban Ayat-ayat Suci al-Qur'an karya Joesoef Sou'yb pada tahun 1975. Q.A. Dahlan Shaleh dan M.D. Dahlan menyusun buku dengan judul Ayat-ayat Hukum: Tafsir dan Uraian Perintah-perintah Dalam al-Qur'an Pada tahun 1976. Pada tahun itu juga muncul al-Qur'an Dasar Tanya Jawab Sumatera Ilmiah yang disusun oleh Nazwar Syamsu. Dilanjutkan pada tahun 1977, seorang kritikus sastra H.B. Jassin menulis al-Qur'an al-Karim Bacaan Mulia tanpa disertai catatan kaki. Masih pada tahun yang sama, Muhammad Ali Usman menulis dengan judul Makhluk-makhluk Halus Menurut al-Qur'an. Bachtiar Surin juga menulis sebuah terjemahan yang disisipi tafsir dengan judul "Terjemah dan Tafsir al-Qur'an: Huruf Arab dan Latin" pada tahun 1978, kemudian Zainal Abidin Ahmad juga menulis Tafsir Surah Yaa-sien pada tahun yang sama. Pada tahun itu juga (1968) Bey Arifin menyusun tafsir dengan judul Samudera al-Fatihah, bahkan sebelumnya, dia juga menyusun buku dengan judul Rangkaian Cerita dalam al-Qur'an yang diterbitkan dua kali yaitu pada tahun 1971 dan1983. Masih pada tahun yang sama (1978) Mafudli Sahli juga ikut menulis dengan judul Kandungan Surat Yasin. Kemudian pada tahun 1979, M. Munir Faurunnama menulis buku dengan judul al-Qur'an dan Perkembangan Alam Raya. Dan pada tahun 1980, Perguruan Tinggi Ilmu-ilmu al-Qur'an menyusun Pancaran alQur'an Terhadap Pola kehidupan Bangsa Indonesia.

Memasuki abad ke-21 terdapat satu karya besar yang lahir dari pemikiran seorang ulama modern yang sangat mumpuni di bidangnya. Adalah Tafsir al-Misbah, sebuah kitab tafsir yang menafsirkan ayat al-Quran secara lengkap 30 Juz. Penulisnya adalah M. Quraish Shihab, seorang ulama terkemuka di Indonesia hingga saat. Karya tafsir ini pertama kali dicetak pada tahun 2003 dan hingga kini 
sudah mengalami puluhan kali cetak ulang dan diterbitkan oleh beberapa penerbit Indonesia. Hingga kini belum ditemukan lagi karya tafsir besar lainnya.

Fenomena ini menjadi bukti bahwa perbauran budaya dan gaya hidup warisan masa pra Islam dapat terjalin dengan baik. Teori-teori akulturasi menjadi sarana yang dapat menggambarkan kondisi ini lebih baik. Definisiakulturasi yang sistematik, pertama kali dikemukakanoleh Redfield, Linton dan Herskovits (1936) yaitu: "Acculturation comprehends these phenomena which result when groups of individuals having different cultures come into continous first-hand contact, with subsequent changes in the original cultural patterns of either or both groups" Dalamperkembangannya, definisiakulturasitersebutbanyakmendapatkritikanparaantro pologpadasaatitu,

halinikarenaadabeberapapoinmenurutmerekasangatsulituntukditafsirkanyaitu: apasebenarnyapengertian "continousfirst-hand contact";(2) apapengertiandari "groups of individuals";

bagaimanakahhubunganantaraakulturasidengankonsepperubahankebudayaandandif

usi; (4) bagaimanakahhubunganantaraakulturasidanasimilasi; dan (5) apakahakulturasisebagaisuatu proses ataukahmenunjukkanpadasuatukeadaan (a process or a condition) .

Sebagai ilustrasi sulitnya menafsirkan definisi akulturasi tersebut menurut para antropolog ketika berhadapan dengan berbagai masalah yang bermunculan, yang mencolok adalah modifikasi kebudayaan yang muncul sebagai akibat kontak yang berlangsung hanya sebentar-sebentar, misalnya yang terjadi di kalangan kaum misionaris atau

pedagang.

Dalambeberapakasusmerekainidapatdianggapsebagaipembawakebudayaan lain. Sekalipunadakesulitanuntukdapatdimasukkansebagaifenomenaakulturasi, agaknyakasustadibisadimasukkandalamruanglingkupstudimengenaiperubahankebud ayaan.Kesulitan dalam melihat kasus tadi sama dengan kesulitan dalam membedakan antara akulturasi dengan difusi. Sekalipun demikian, baik akulturasi maupun difusi, dapat mewakili suatu perubahan kebudayaan, yaitu sebagai Melayu dan terjadinya penyebaran (transmision) kebudayaan di kalangan kelompokkelompok yang tersebar di Sumatera. Dalam hubungan itu Herskovits (1948) dalam Purwanto dikatakan bahwa dalam memecahkan masalah itu, lebih mendasarkan atas pertimbangan bahwa difusi adalah suatu penyebaran kebudayaan yang telah terjadi to be achieved cultural transmission; sedangkan akulturasi adalah proses penyebaran kebudayaan is cultural transmission in process .DalamsalahsatutulisannyaThurnwarld (1932) dalamPurwanto disebutkan bahwa:akulturasiadalah "Acculturation is a process, not an isolated event" . Sebagaiimplikasidaripernyataannyatersebutlebihmenekankansuatu proses yang terjadipadatingkat individual, karenanyasuatu proses adaptasiterhadapkondisikehidupanbaru yang disebutdenganakulturasi.

Pergerakan Islam di Nusantara sepertinya tak pernah lepas dari pergerakan dan persebaran etnis Melayu, terutama pada abad ke 15 hingga menjelang abad ke 16 integritas tradisi Melayu dan Islam terlihat semakin harmonis. Ajaran Islam (seolah) menjadi sendi utama atas berbagai perkembangan kehidupan etnis Melayu dimanapun berada. Realita ini merupakan puncak pembuktian atas teori-teori yang muncul mengenai kedatangan Islam ke wilayah Negeri di Bawah Angin ini, yang salah satunya bahwa tradisi pedagang Arab dan aktifitas perdagangannya adalah penyebab utama menyebarnya Islam di wilayah Nusantara.?

Dalam analisa Anthony Ried "Undang-Undang Melayu abad ke-16 dan abadabad sesudahnya, meniru model Arab secara ketat dalam hal perniagaan, investasi, 
jatuh pailit, dan hukum waris ". Ungkapan Reid merupakan gambaran atas persebaran ajaran Islam yang sudah cukup meresap dalam kehidupan masyarakat Melayu yang notabene adalah masyarakat terbuka, yang peletakkan dasar kepercayaan asalnya adalah non-Islam. Akibat dari keberpihakan penguasa terhadap ajaran Islam dan sekaligus menerapkannya ke dalam berbagai peraturan pemerintahan, maka pergerakan atmosfir keilmuan Islam pun mendapatkan ruang yang cukup luas, sehingga tidak mengherankan apabila di kemudian hari terdapat penduduk yang berminat untuk melaksanakan ibadah haji sekaligus menetapkan diri untuk menuntut ilmu-ilmu Islam disepanjang jalur haji atau bahkan menetap di Mekkah dan Madinah. Selain karena ditemukan dalam catatan sejarah bahwa terdapat beberapa ulama besar yang menetap di Semenanjung Arabia adalah berasal dari tanah air, juga karena akitivitaskeilmuan Islam di beberapa kerajaan Islam Nusantara memiliki intensitas yang cukup baik. Hal ini juga dapat diduga menjadi pemicu munculnya minat penduduk untuk memperdalam ilmu keislaman sesuai dengan porsi ketimuran. Dan bukan tidak mungkin pula minat ini tumbuh sebagai akibat dari penyimpangan ajaran yang juga kerap ditemukan dalam kehidupan sehari-hari, baik dari kalangan penguasa,priyayi, maupun rakyat jelata.

Pembuktian dari analisa Ried ini ditemukan dalam bukti sejarah yang menyebutkan bahwa Palembang menjadi tempat pertama pencetakan mushaf alQuran di luar Arab. Dalam kajian Jeroen Pieters, angka tahun $1848 \mathrm{M}$ yang menunjukkan bahwa Palembang telah memiliki al-Quran cetak yang didalamnya terdapat beberapa keterangan yang menyebutkan bahwa mushaf Al-Qur'an cetakan tertua berasal dari Palembang, hasil cetak batu (litografi) Haji Muhammad Azhari bin Kemas Haji Abdullah, selesai dicetak pada 21 Ramadan 1264 (21 Agustus 1848). Sejauh yang diketahui hingga kini, inilah mushaf cetakan tertua di Asia Tenggara (di luar Jazirah Arab). Mushaf kuno yang diketahui, sampai saat ini, hanya ada pada koleksi Bapak Abd Azim Amin, Palembang (Gambar 1).

"Sebermula adalah mengecap al-Qur'an al-'Azim ini di atas Paris Lithographique yakni di atas impitan kayu batu dengan khat suratan fakir ila Allahi ta'aala al-Haji Muhammad Azhari ibnu Kemas al-Haji Abdullah, Palembang nama negerinya, Syafi'i mazhabnya, Asy'ari iktikadnya, Junaidi ikutannya, Sammani minumannya. Maka adalah yang mengerjakan cap ini adalah Ibrahim ibnu Husain, Sohab Nagur nama negerinya Singapura tempat kediamannya daripada murid tuan Abdulah ibnu Abdulkadir Munsyi Malaka. Telah selesailah daripada mengecap dia pada hari senin dua puluh satu hari daripada bulan Ramadhan atas rukyat negeri Palembang pada Hijrah Nabi-salallahu alaihi wasallama- seribu dua ratus enam puluh empat tahun 1264. Maka membetuli pada dua puluh satu hari bulan Agustus tarikh Masehi seribu delapan ratus empat puluh delapan tahun dan enambelas hari bulan Mishra tarikh kubti seribu lima ratus enampuluh empat tahun (1564) dan sembilan hari bulan Ab tarikh Rumi dua ribu seratus lima puluh sembilan tahun dan dua puluh empat hari bulan Isfandar mah tarikh Farsi seribu dua ratus tujuh belas tahun (1217). Maka adalah banyak bilangan Qur'an yang dicap itu seratus lima Qur'an (105). Maka perhimpunan mengerjakan dia limapuluh hari, maka dalam satu hari dua Qur'an 3 juz, dan tempat mengerjakan cap itu di dalam negeri Palembang di dalam Kampung Tiga Ulu pihak kiri mudik Kampung Demang Jalaksana Muhammad Najib ibnu Almarhum Demang Wiralaksana Abdulkhaliq. Mudah-mudahan mengampuni Allah swt bagi mereka yangmenyurat dia dan yang mengerjakan dia dan yang membaca akan dia dan bagi segala ibu bapak mereka itu dan segala muslim laki-laki dan perempuan dan segala ibu bapak mereka itu. Wa sallallahu ala khairi khalqihi sayyidina Muhammad wa alihi wa sahbihiwasallam. 
Mushaf cetakan Azhari lainnya, dengan tahun yang lebih muda, selesai dicetak pada Senin, 14 Zulqa'dah 1270 H (7 Agustus 1854) di Kampung Pedatu'an, Palembang. Von de Wall, seorang kolektor naskah abad ke-19, pernah membuat catatan lengkap mengenai mushaf ini atas permintaan Residen Belanda di Palembang yang dimuat dalam TBG 1857. Berdasarkan catatan itu, mushaf cetakan tahun 1854 kemungkinan kini ada dalam koleksi Perpustakaan Nasional RI Jakarta . (gambar.2.).

Dengan adanya cetakan mushaf tahun 1854 itu, dapat diketahui bahwa percetakan milik Azhari, paling kurang, produktif dalam masa tujuh tahun (18481854). Meskipun demikian, luasnya peredaran mushaf hasil cetakan Azhari tidak diketahui dengan pasti, karena langkanya bukti.

Dua bukti di atas menggambarkan kondisi kemakmuran Islam di Nusantara, khususnya di wilayah Sumatera Selatan. Sehingga al-Quran cetak menjadi kebutuhan utama, bukan hanya dalam konsumsi dakwah melainkan masyarakat luas membutuhkannya untuk mengekspresikan ketauhidan mereka kepada Allah melalui pembacaan rutin al-Quran. Dalam rangkaian pendidikan Islam, wilayah Sumatera Selatan mempunyai metode tersendiri dalam mengajarkan al-Quran kepada penduduknya. Maka transmisi penyampaian ajaran, tidak hanya berkutat pada metode satu arah atau ceramah, namun Palembang sudah memiliki tradisi pengkajian dan penelitian ayat yang terdapat dalam mushaf-mushaf tersebut.

Diantara beberapa ulama besar yang pernah muncul di masa awal kesultanan Palembang terdapat nama Syeikh Abdus Samad al-Palimbani yang merupakan pemikir, pengontrol, pengkritik serta pelaku pengajaran al-Quran yang tergolong modern pada masanya. Meski beliau lahir setelah setengah abad cetak pertama alQuran hadir di Palembang, namun perannya dalam pengajaran dan penerjemahan al-Quran tidak dapat diabaikan, terutama terhadap perkembangan pemahaman Islam di Sumatera Selatan. Hal ini karena beliau adalah seorang muslim yang tekun mencari ilmu Islam dari masa mudanya, yang dimulai di daerah Patani Thailand hingga memasuki masa dewasa, beliau belajar dari banyak ulama besar di Mekkah dan Madinah.Syaikh Abdus Saman al-Palimbani adalah salah satu tokoh Islam yang meninggalkan banyak jejak Islam pada tradisi masyarakat Sumatera Selatan khususnya, dan hal ini memberikan sumbangan besar pada peradaban Isalam pada masyarakat Melayu pada umumnya. Walaupun terjemahan al-Quran secara tekstual tidak ditemukan dalam karya-karya beliau, tetapi jejak pemikiran dan ajaran beliau telah banyak melekat dalam prilaku Islam masyarakat Sumatera Selatan.

Beberapa kajian budaya menyatakan bahwa Islam telah membawa peradaban maju bukan hanya pada bidang spiritual. Namun lebih dari itu, Islam telah merambah ke seluruh bagian kehidupan manusia, seperti ekonomi, perdagangan, pendidikan,fashion, pertahanan dan ketahanan masyarakat, lingkungan sosial, seni, dan lain-lain. Tradisi yang diwariskan kepada generasi sekarang ini adalah bentuk tradisi yang terdampak ajaran Islam. Karena kedatangan Islam tidak menghancurkan pola lama yang sudah ada, namun mayoritasnya lebih mengantarkan orang Melayu kepada pola kehidupan yang lebih beradab. Melalui ajaran-ajaran yang humanis, telah berhasil membuat orang Melayutidak menolak mentah-mentah semua kewajiban yang dibebankan kepada seseorang yang menjadi penganut agama Islam. Hal inilah menjadi dasar kesuksesan Islam yang tersebar secara meluas di tanah yang dihuni orang-orang Melayu ini. Kebanggaan mereka terhadap Islam bukan hanya tergambar dari kuantitas pemeluk yang terus meningkat, namun seluruh prilaku dan budaya yang diterapkan kemudian menempatkan al-Quran sebagai sumber rujukan utama. 
Perintah menutup aurat contohnya; diketahui sebagai kewajiban mutlak bagi setiap kaum muslim yang telah memasuki masa akil balighnya, kondisi ini dimaknai oleh masyarakat Sumatera Selatan dengan ekspresi mereka sendiri. Dalam beberapa tempat di al-Quran disebutkan aturan konkrit mengenai batasan busana yang wajib dikenakan oleh laki-laki dan perempuan muslim. Sudah menjadi kebiasaan bagi masyarakat Sumatera Selatan untuk mengenakan busana khusus sholat bagi perempuan, yang biasa disebut telekung (berupa kerudung yang dibuat dari kain panjang dan lebar yang menutupi tubuh bagian atas hingga bawah perut serta bagian bawahnya dilengkapi dengan sarung yang menutupi tubuh bagian bawah hingga melewati mata kaki) dan bagi laki-laki berupa busana khusus yang disebut dengan bajukoko, kopcah(penutup kepala)dan sarung(kain penutup tubuh bagian bawah dari bagian perut hingga kaki), adalah hasil interpretasi cerdas yang dilakukan masyarakat Melayu dalam upaya melaksanakan perintah Allah tentang menutup aurat. Hal ini pada awalnya teraplikasi dalam pelaksanaan perintah sholat wajib yang dilakukan 5 waktu dalam sehari,yang dalam pelaksanaannya sangat dilarang untuk menampakkan aurat. Dalam pemilihan bentuk busana, selain karena terinspirasi busana yang telah ada di jazirah Arab, sebagai negeri tempat Islam berasal. Para penganut Islam di tanah Melayu ini menempuh model terjemahan mereka sendiri, sehingga diiringi dengan kreatifitas yang didasari oleh alam Nusantara yang berbeda dengan Arab, mereka menemukan model busana tersendiri yang pada awalnya lebih banyak digunakan hanya ketika melaksanakan sholat 5 waktu saja. Namun beriringan dengan waktu dan perkembangan pemahaman yang makin baik, maka busana ini kemudian mendapat sentuhan modifikasi fashion yang canggih hingga kini dapat dikenakan sebagai busana harian dan dapat diterima masyarakat dengan baik.

Dalam standar etika dan prilaku, masyarakat di wilayah Sumatera Selatan sangat akrab dengan pola hidup yang berprinsip akhlak karimah seperti yang diwariskan oleh Rasulullah Muhammad SAW. Batasan pergaulan antara laki-laki dan perempuan diatur ketat dalam kitab hukum pada masa kerajaan Palembang, yang dikenal dengan kitab Simbur Cahaya. Selain masalah pergaulan, kitab ini juga mengatur tata cara berdagang dan juga pendidikan antar anggota keluarga dan anggota masyarakat. Harmoni kehidupan sosial Melayu dan Islam dalam kehidupan masyarakat Palembang pada masa kini, secara konkrit masih dapat ditemui. Misalnya dapat dilihat dari susunan ruangan dalam rumah Limas (rumah tradisional Palembang) yang memiliki pemisahan ruanganyang solid, secara umum didasarkan pada ajaran Islam yang sangat menghargai keberadaan anggota yang berbeda usia dan jenis kelaminnya. Batasan-batasan yang muncul dalam ajaran Islam dan teraplikasi dalam atmosfer Melayu Sumatera Selatan merupakan bentuk nyata efek penerjemahan yang terjadi terhadap manuskrip-manuskrip ajaran Islam, yaitu alQuran.

\section{Penutup}

Perjalanan Islam di Nusantara ternyata telah menapaki jalannya tersendiri. Pemahaman umat yang sebelumnya beragama kepercayaan juga telah membuat warna tersendiri dalam dunia dakwah Islam. Dengan tetap menggunakan bahasa aslinya, yaitu bahasa Arab, al-Quran tetap tampil di tengah masyarakat Melayu yang memiliki kepribadian terbuka. Secara prinsip tidak ada ajaran yang berbeda antara Islam yang berkembang di jazirah Arab dan masyarakat Melayu. Namun kemudian, para penganut Islam non Arab ini tidak menggunakan bahasa Arab mengajarkan kandungan al-Quran tersebut. 
Teori akulturasi adalah salah satu jalan untuk menemukan bentuk tradisi asal yang telah dipengaruhi Islam yang masih berlangsung hingga kini. Baik dari sisi prinsip maupun manifestasi aktif. Bahkan pada masa sekarang, sulit untuk membedakan antara bentuk tradisi asli Melayu dengan tradisi yang telah mendapatkan perngaruh Islam. Penyebab utama terjadinya hal ini adalah karena transmisi penyampaian ajaran al-Quran yang berbahasa Arab, tidak lagi mendapatkan benturan yang berarti. Karena pola penerjemahan al-Quran yang semakin baik dari waktu ke waktu.

Berbagai bentuk tradisi, budaya dan bahasa sebagian besarnya kini telah dipengaruhi oleh ajaran Islam. Selain itu, profil para ahli ilmu agama dan para ulama pun hadir dalam balutan darah asli Melayu, tanpa pencampuran Arab sedikitpun. Munculnya berbagai karya terjemah dan tafsir al-Quran juga turut membuktikan dinamisasi penterjemahan yang akurat mengenai ajaran Islam yang berasal dari alQuran.Sehingga tidak mengherankan apabila Islam disebut sebagai pembawa peradaban maju dalam struktur masyarakat Melayu, terutama masyarakat Sumatera Selatan hingga kini. 


\section{Daftar Pustaka}

Abdullah bin Nuh dan D Shahab "Catatan Tentang Mulanya Masuknya Islam ke Indonesia”, Risalah Seminar Sejarah Masuknya Agama Islam Ke Indonesia, (Medan:Waspada,1963),

Abu Zaid, Nasr Hamid, Mafhun an-nash dirasah fi 'ulum Al-Quran, diterjemahkan oleh oleh LKiS “Tekstualitas AI-Quran, (Cet. IV, LKiS; Yogyakarta; 2005)

Abu Zaid, Nasr Hamid, Tekstualitas Al-Quran, Kritik Terhadap Ulumul Qur'an. (Cet. IV, Yogyakara; LKiS, 2005), h. 45.

Adnan Amal, Taufik, Rekonstruksi sejarah AI-Quran ( Cet. I, FKBA, Yogyakarta, 2001), h. 45

Al-Syahrastani, Kitab Nihaya al-Iqdam fi, ilm al-kalam, Ed(Alfred Guillaume, London: Oxford University Press, 1934), h. 371.

Asmawi, Muhammad Said, Againstlslamic Extrmism (Carolyin Fluehr-Lobban, The Board of Regents ofd the state of Florida, 1998.

Assyaukani, Luthfi Upaya Merumuskan Keberagamaan yang Dinamis,( Cet. I, Jakarta; 2005), h. 1

At-Tamimi, Abuya Syeikh Imam Ashaari Muhammad. Meninjau Sistem Pemerintahan Islam. (Jakarta: Giliran Timur. 2004).

Azra, Azyumardi. 2013. Jaringan Ulama Timur Tengah dan Kepulauan Nusantara Abad XVII dan XVIII. Jakarta: Kencana Prenada Media Grup.

Badan Penelitian dan Pengembangan Agama, Mengenal Mushaf Al-Qur'an Standar Indonesia, Jakarta: Departemen Agama RI, 1984-1985.

Bruinessen, Martin van, Kitab kuning, pesantren dan tarekat: Tradisi-tradisi Islam di Indonesia, Bandung: Mizan, 1995.

Fakhruddin, Fuad Muh, Sejarah Perkembangan Pemikiran Islam, (Cet. Kedua, Bandung: Mizan, 2000.

Gallop, Annabel Teh, "Islamic manuscripts from the Philippines in U.S. Collections: a preliminary listing, including two printed Qur'ans,http://www.oovrag.com/bibliography/bibliography13.shtml

Hanafiah, Djohan. 1995. Melayu- Sumatera Citra Budaya dan Sejarah Palembang. Jakarta: PT Raja Grafindo Persada.

Jeroen Peetiers, Kaum Tuo - Kaum Mudo, Perubahan Religius di Palembang 1821 1942, (Jakarta:INIS, 1997).

Jeroen,Peeters, "Palembang revisited: Further notes on the printing establishment of Kemas Haji Muhammad Azhari, 1848", International Institute for Asian Studies (IIAS)Yearbook 1995, 1995, h. 181-190.

Proudfoot, lan, "Malay books printed in Bombay: a report on sources for historical bibliography”, Kekal Abadi, 1994, 13 (3): 1-20. 
Salim, Erwin Y, “Gairah Penerbitan AI-Qur'an Indah”, Gatra, 7 September 2011.

Sudrajat, Enang, "Perkembangan penerbitan dan problema pentashihan", makalah pada Lokakarya Penerbit Mushaf Al-Qur'an, Bekasi, 29-30 Maret 2011 (tidak terbit).

Yunardi, E Badri, "Sejarah Lahirnya Mushaf Standar Indonesia”, Lektur, 2005, 3 (2): 279-300. 